\title{
THE MIXED LEGACY OF MAGNA CARTA FOR AMERICAN RELIGIOUS FREEDOM
}

\author{
STEVEN K. GREEN
}

Fred H. Paulus Professor of Law and Affiliated Professor of History, Willamette University

\begin{abstract}
In 2015 Magna Carta celebrated its 80oth anniversary. The Great Charter has been widely heralded as a fount of many rights that are highly valued in British and American law. One right that people have identified in the Carta is that of religious freedom. Magna Carta contains two provisions guaranteeing freedom of the church from government authority. In 20I3, the United States Supreme Court relied on that authority in a ruling that affirmed the principle of religious autonomy. This article argues that relying on the legacy of Magna Carta for the principle of religious freedom is tenuous: the document had little influence on the development of the First Amendment. Even Magna Carta's authority for the principle of church autonomy is overstated, as the Carta had nothing to do with the development of that principle in American law. Finally, judicial reliance on Magna Carta for the principle of religious freedom risks elevating protections for religious institutions over the interests of individuals. As a result, the legacy of Magna Carta for the principle of religious freedom is mixed, at best.
\end{abstract}

KEYWORDS: Magna Carta, religious freedom, church autonomy, ministerial exception

The year 2015 marked the 80oth anniversary of the sealing of Magna Carta in the pastures of Runnymede. This anniversary did not go unnoticed, particularly in the United States, where the "Great Charter" is apparently revered more than it is in Great Britain. ${ }^{\mathrm{I}}$ Magna Carta has long received hagiographic acclaim as the origin of the concept of the "rule of law," central to the Western legal tradition, and as the birthplace of individual rights, particularly those that serve as a bar to government overreaching and tyranny. ${ }^{2}$ This anniversary was no different in the accolades bestowed on the Charter. A new book proclaims the conventional view in its title: Magna Carta: The Birth of Liberty. And in her foreword to a 2014 compilation on Magna Carta and the Rule of Law, former United States Supreme Court Justice Sandra Day O'Connor asserts that Magna Carta was "a central inspiration to our founding fathers in framing our Constitution."3

I See "David Cameron's Ignorance over Magna Carta and Rule Britannia Exposed,” Telegraph, Sept. 27, 20I2; “Magna Carta's Meaning Was a Mystery to Prime Minister David Cameron Three Years Ago," Huffington Post, June I $5,2015$.

2 See H. D. Hazeltine, "The Influence of Magna Carta on American Constitutional Development," Columbia Law Review I7, no. I (1917): I-33; A. E. Dick Howard, The Road from Runnymede: Magna Carta and Constitutionalism in America (Charlottesville: University Press of Virginia, 1968).

3 Dan Jones, Magna Carta: The Birth of Liberty (New York: Viking Press, 2015); O'Connor, foreword to Magna Carta and the Rule of Law, ed. Daniel Barstow Magraw, Andrea Martinez, and Roy E. Brownell (Chicago: American Bar Association, 20I4), xi-xvii, at xiv. 
While justices on the Supreme Court have frequently noted the influence of Magna Carta on American law, 4 the document received significant "shout outs" in two recent cases. In his dissenting opinion in Obergefell $v$. Hodges, the 2015 marriage equality case, Justice Thomas relied extensively on Magna Carta to advocate a narrow understanding of "liberty" for the purposes of due process of law. (No doubt, the barons at Runnymede, being feudal lords, would have shared Justice Thomas's cramped view of individual liberty. $)^{5}$ More significant, however, and the focus of this article, was Chief Justice Robert's opinion for a unanimous court in the 2013 Hosanna-Tabor Evangelical Lutheran Church and School v. EEOC. Hosanna-Tabor involved the question of whether a constitutional mandated "ministerial exception" exists within employment nondiscrimination laws, such that houses of worship and religious organizations have complete discretion to select their religious leaders without oversight of government regulation. All of the justices agreed that the concept of religious autonomy enshrined in the free exercise and establishment clauses mandates such an exception from the law. Speaking for the Court, Chief Justice Roberts declared that the idea of "church freedom" from government control found its genesis in the "very first clause of Magna Carta." Roberts noted that in that I2 I 5 document, the barons and King John agreed that "the English church shall be free, and shall have its rights undiminished and its liberties unimpaired." He explained that just so there was no misunderstanding as to what a "free church" meant, the authors of the Charter clarified that it included, if not prioritized, the "freedom of elections" of church officials. This, Chief Justice Roberts remarked, was a right "thought to be of the greatest necessity and importance to the English church." The heritage of a "free church" made its way across the Atlantic Ocean to the British-American colonies and was embraced by the colonialists and then by the nation's founders. "By forbidding the 'establishment of religion' and guaranteeing the 'free exercise thereof,' the Religion Clauses ensured that the new Federal Governmentunlike the English Crown-would have no role in filling ecclesiastical roles," Roberts asserted. ${ }^{6}$ Thus the idea of the autonomy of religious institutions from government control, central to the purposes of the religion clauses, can be traced directly back to Magna Carta.

It is a good story, and like good stories this account contains an element of truth. Yet the claim that American ideas of religious freedom find their basis in Magna Carta contains as much fiction as fact. 7 This article offers several points. First, despite the pervasive belief among many lawyers, politicians, and members of the Court-not to mention the general public-Magna Carta's influence on American constitutional development is tenuous at best. When one considers its specific impact on American ideas of religious freedom we do see a faint influence on the idea of church autonomy generally, despite the fact that the justices did not rely on Magna Carta in the foundational church autonomy decisions. ${ }^{8}$ When it comes to Magna Carta's specific legacy for the practice of independent selection of clergy, the connection becomes even more tenuous, despite Chief Justice

4 See Stephen J. Wermiel, "Magna Carta in Supreme Court Jurisprudence," in Magraw, Martinez, and Brownell, Magna Carta and the Rule of Law, III-40, at III (noting that Magna Carta is referred to in more than I70 Supreme Court cases).

5 Obergefell v. Hodges, I35 S. Ct. 2584, 2640 (2015) (Thomas, J., dissenting).

6 Hosanna-Tabor Evangelical Lutheran Church and School v. Equal Employment Opportunity Commission, I30 S. Ct. 694, 702-03 (2013).

7 See David Little, "Differences over the Foundation of Law in Seventeenth- and Eighteenth-Century America," in Magna Carta, Religion and the Rule of Law, ed. Robin Griffith-Jones and Mark Hill (Cambridge: Cambridge University Press, 2015), I36-54.

8 Watson v. Jones, 80 U.S. 679 (I872); Kedroff v. St. Nicholas Cathedral, 344 U.S. 94 (I952); Presbyterian Church v. Hull Memorial Presbyterian Church, 393 U.S. 440 (1969); Serbian Orthodox Diocese v. Milivojevich, 426 U.S. 696 (1976). 
Roberts's claim otherwise. And finally, by finding that an absolute church autonomy right exists in the selection of clergy, the Court followed a failing of religious freedom that is enshrined in and legitimated by Magna Carta. In Hosanna-Tabor, the Court followed a precedent set out in Magna Carta of elevating the "freedom of the church" over individual religious freedom. In that notions of religious freedom and rights of conscience have developed significantly since the thirteenth century, not to mention ideas of individual rights generally, it is perhaps unfair to call Magna Carta's limited approach to religious freedom a "failing." The failing is not so much with the Great Charter but with our inclination to project contemporary understandings of rights onto ancient sources and then to rely on those sources for present authority. By citing Magna Carta as authority, the Hosanna-Tabor Court reversed the priority of the Founders when it came to matters of religious freedom in America, placing the independence of the church over the religious freedom of individuals. The tragedy of relying on Magna Carta as a source of American religious freedom is that that idea then becomes constricted by the limitations contained in Magna Carta. It is, to paraphrase the title of a popular song during the founding period, "the world turned upside down." 9

In the first part of this article I consider the general influence of Magna Carta during the colonial period and on the framing of the Constitution. I then examine Magna Carta's influence on ideas of religious liberty, in particular, principles of church autonomy generally and of independence of the clergy specifically. Finally, I discuss what I call the tragedy of Magna Carta - or at least of judicial reliance on it - for the purposes of understanding religious freedom. While Magna Carta's influence on the idea of church autonomy can be justly celebrated, Magna Carta had nothing to do with principles of individual religious freedom, and it even created a negative inference to the opposite. Magna Carta's legacy for religious freedom is thus mixed, at best.

\section{MAGNA CARTA AND AMERICAN CONSTITUTIONAL DEVELOPMENT}

No one contests the importance of Magna Carta for the development of ideas about rights and legal relationships between the sovereign and the citizenry. Its influence on the law and on constitutional ideas has been general, as with its impact on the development of the common law, and specific, as to particular rights such as due process of law. ${ }^{\circ}$ However, as one scholar has stated, its lasting reputation has always been something of a surprise. King John repudiated the agreement almost as soon as it was sealed, and later monarchs would ignore if not repudiate its provisions. Later renditions of the Charter would omit or rewrite various provisions, such that the contents of the document were not settled until it was enacted into statutory law in I297. Its legacy "can only be explained by the later history of Magna Carta, not by what it was in I 2 I 5 ." II

9 Benson Bobrick, Angel in the Whirlwind: The Triumph of the American Revolution (New York: Penguin Books, I997), 463 .

Io Many scholars trace the modern notion of due process of law to chapter 39 of Magna Carta. Hazeltine, "The Influence of Magna Carta," 3-5; Frederick Mark Gedicks, "An Originalist Defense of Substantive Due Process: Magna Carta, Higher-Law Constitutionalism, and the Fifth Amendment," Emory Law Journal 58, no. 3 (2009): 585-673, at 596-98.

I I R. H. Helmholz, "Magna Carta and the Ius Commune," University of Chicago Law Review 66, no. 2 (I999): $297-37$ I, at 298,362 . 
And then, the significance of Magna Carta has less to do with how "later history" interpreted and applied its provisions and more to do with what Magna Carta came to symbolize writ large: the rule of law. As another scholar has noted,

Magna Carta has been venerated for eight centuries. It has become a symbol for the rule of law as well as English and Western exceptionalism. Magna Carta has, in this sense, functioned as a myth and an icon. ${ }^{\mathrm{I}}{ }^{2}$

Thus it is the symbolism of Magna Carta, or its "myth," rather than its actual precedent, which has been most influential in the United States. As renowned Supreme Court Justice Benjamin Cardozo once remarked, " $[\mathrm{w}]$ hat lives in the charter today is the myth that has gathered around it - the things that it has come to stand for in the thought of successive generations." ${ }^{3} 3$

Edward Corwin and others have noted that much responsibility for elevating the significance of Magna Carta, particularly among American colonialists, rests with Sir Edward Coke who, writing in the early I600s, identified rights contained in Carta with fundamental higher law, a law that bound the sovereign. Coke also saw Carta as informing, if not being integrated into the common law, particularly those concepts that reinforced those rights and privileges of Englishmen. Of chief significance for Coke was chapter 39, which provided that "No free man shall be seized or imprisoned, or stripped of his rights or possessions ... or deprived of his standing in any way ... except by the lawful judgment of his equals or by the law of the land.” ${ }^{4}$ Later British statutes, and those American colonial lawyers for whom Coke's Institutes were most influential, equated "law of the land" with "due process of law." ${ }_{5}$

A handful of colonial charters and laws referred to Magna Carta or to its specific provisions, such as a 1638 bill by the Maryland Assembly that expressly declared "that the inhabitants shall have all their rights and liberties according to the great charter of England." ${ }^{6} 6$ More common was recurring language in a majority of colonial charters guaranteeing the colonists the "liberties, franchises, and immunities" of Englishmen, a phrase, according to A. E. Dick Howard, traceable to Magna Carta. ${ }^{17}$ That colonialists revered Magna Carta as a source of fundamental rights of Englishmen is demonstrated by a controversy that occurred in mid-seventeenth century. A dispute arose in Massachusetts Bay in 1646 over the enactment of the Body of Liberties, a comprehensive code that regulated commercial, criminal, and behavioral conduct. Dissenters raised two objections to the Body of Liberties: First, its provisions were based in large part on the Pentateuch of the Bible, at the expense of the common law. Second, the Body of Liberties was never published, which gave significant interpretative and enforcement discretion to magistrates. A group of petitioners, led by Dr. Robert Child, objected on both grounds that they were being deprived of their rights of Englishmen and the guarantees of the common law. In a defensive reply to the petitioners, the General Court, the colony's legislative body, went out of its way to highlight those provisions of the Body of Liberties that were similar to Magna Carta and the common law, noting that no

I 2 Maleiha Malik, "Magna Carta, Rule of Law and Religious Diversity," in Griffith-Jones and Hill, Magna Carta, Religion and the Rule of Law, 248-63, at 248.

I 3 Benjamin N. Cardozo, "Faith and a Doubting World," in Selected Writings of Benjamin Nathan Cardozo, ed. Margaret E. Hall (New York: Fallon, 1947), 99-106, at 104.

I4 Magna Carta (I2 I 5), https://www.bl.uk/magna-carta/articles/magna-carta-english-translation; Edward S. Corwin, The "Higher Law" Background of American Constitutional Law (Ithaca: Cornell University Press, I955), 30-35.

I 5 Gedicks, "An Originalist Defense of Substantive Due Process," 596-6I4.

I6 Howard, The Road from Runnymede, 54.

I7 Ibid., I4-23, at I5. 
less than nine provisions in the Body paralleled Magna Carta. ${ }^{18}$ Still facing pressure, the General Court then revised the code to incorporate greater aspects of the common law, while lessening its religious shorings, publishing it now as the Lawes and Libertyes of Massachusetts. Seeking to put the best light on the fiasco, John Winthrop wrote in his History of New England that

[t] he deputies having conceived great danger to our State in regard that our magistrate for want of positive law in many cases might proceed according to their discretion, it was agreed that some men should be appointed to frame a body of grounds of law, in resemblance to a Magna Carta which ... should be received for fundamental law. ${ }^{19}$

Magna Carta's impact on colonial legal development was much greater than its references in specific legal provisions, however. Generally, American colonialists of the seventeenth and eighteenth centuries perceived Magna Carta as an integrated part of a larger body of laws and acts, such as the Petition of Right, the Habeas Corpus Act, and the Bill of Rights, all of which reinforced and guaranteed the fundamental rights and liberties of Englishmen. American lawyers and politicians pointed to this body of documentary evidence when the political conflicts with Parliament arose in the I760s. In particular, American colonialists appropriated Coke's view of Magna Carta's integration into the common law as a restraint on the excesses of Parliament and on that body's assumption that its acts were, by definition, consistent with the British constitution. Leading patriot and tract writer James Otis cited Magna Carta and Coke's Institutes to declare that Parliament was not "the final arbiter of the justice and constitutionality of its own acts." 20 And one finds references to Magna Carta as a source of the essential liberties of Englishmen, along with occasional quotations from Carta's provisions, in the resolutions by various towns and committees of correspondence between 1765 and I775. Still, according to Bernard Bailyn, the sober-minded revolutionaries knew that written laws-"even the great declarations like Magna Carta - [did] not create liberties; 'they must be considered as only declarations of our rights, and in affirmance of them." ${ }_{21}$

Despite its rhetorical use during the American Revolution, the myth of Magna Carta for American constitutional formation was likely greater than the impact of any of its specific provisions. Legal scholar Philip Kurland, writing on the charter's 75 oth anniversary, observed that its "specific influence on current American constitutional doctrine is difficult to discover." The influence of Carta on American Constitutionalism was a "noble lie," Kurland concluded. ${ }^{22}$ The facts seem to bear this out. The index to James Madison's Notes of Debates in the Federal Convention, recognized as the most authoritative source, contains no reference to Magna Carta as a topic of discussion. This may say more about Madison's note taking and editorializing, as it is hard to believe that no delegate ever mentioned Magna Carta, at least in passing. Still, Carta

I8 Ibid., 35-48; “The Massachusetts 'Parallels' of I646," in ibid., appendix, 40I-II.

I9 Hazeltine, "The Influence of Magna Carta," 9-II; George Lee Haskins, Law and Authority in Early Massachusetts (New York: Macmillan, 1960), I24-40; Steven K. Green, Inventing a Christian America (New York: Oxford University Press, 2015), 84-86.

20 Gedicks, "An Originalist Defense of Substantive Due Process," 6r6; Hazeltine, "The Influence of Magna Carta," 6.

2 I Bailyn, The Ideological Origins of the American Revolution (Cambridge, MA: Belknap Press of Harvard University Press, 1967), I87. See also Donald S. Lutz, The Origins of American Constitutionalism (Baton Rouge: Louisiana State University Press, 1988), 59; Gedicks, "An Originalist Defense of Substantive Due Process," 6I4-2I; Howard, The Road from Runnymede, I70-87.

22 Kurland, "Magna Carta and Constitutionalism in the United States: 'The Noble Lie,"” in The Great Charter: Four Essays on Magna Carta and the History of Our Liberty (New York: Pantheon Books, 1965), 48-74. 
is not referenced in the recorded debates regarding habeas corpus, bills of attainder, and ex post facto laws, the most likely places for some attribution. This overall lack of attribution may be explained by the fact that the drafters' primary concerns in creating a new government were over organization and distributions of powers; "[f]or such a project Magna Carta furnished little guidance." ${ }_{23}$ The authors of the Federalist Papers mention Magna Carta only once, in Alexander Hamilton's number 84, where he uses the checkered history of the Carta as an example of the inefficiency of written bills of rights. Yet Hamilton lost that argument. ${ }^{24}$

A. E. Dick Howard maintains that it is with the Bill of Rights, rather than the Constitution itself, where "we find the bridge between Magna Carta ... and the Charter's legacy in America." 25 Donald Lutz has noted that out of the twenty-seven separate rights contained in the Bill of Rights, six of them, or about 20 percent, were first stated in Magna Carta. ${ }^{26}$ Depending on one's perspective, that number is either significant or shows that the Founders' ideas of rights came from many sources other than the Great Charter. In fact, in his speech introducing the proposed Bill of Rights to the House of Representatives on June 8, I789, Madison argued that the rights of trial by jury, freedom of the press, and liberty of conscience, "those choicest privileges of the people," were not secured by the Magna Carta and were "unguarded in the British constitution." 27 Others concurred that Magna Carta, which had been amended by Parliament several times, represented a poor model. Surprisingly, even the various drafts of the Fifth Amendment, which contains the due process clause, and its supporting documents, are bereft of reliance on Magna Carta. That absence may simply reflect an unspoken view, reinforced by William Blackstone's influential Commentaries, that the concept of due process of law had sprung from Magna Carta. If so, the Framers may simply have accepted the connection between due process and Magna Carta, negating the need for any such attribution. The founding generation's familiarity with Magna Carta makes that explanation unlikely. Overall, the direct influence of Magna Carta on American constitutional formation is fleeting at best. One right contained in the First Amendment that can be traced to the Carta is the right to petition the government for grievances. But the free exercise and nonestablishment clauses, like freedom of speech, have no such lineage. ${ }^{28}$

\section{MAGNA CARTA'S LEGACY FOR RELIGIOUS FREEDOM}

With that in mind, let us turn to the question of Magna Carta's impact on the development of religious liberty in the United States. One could argue there are two related areas of American churchstate doctrine where one can see the "long shadow" of the Magna Carta. Both areas concern the autonomy of churches and houses of worship. The first is a more general autonomy concern: the ability of churches to determine their doctrine and control their internal operations free from either

23 James Madison, Notes of Debates in the Federal Convention of 1787 (Athens: Ohio University Press, I984); Howard, Road from Runnymede, 220 ("Magna Carta may never have been mentioned at all during the debates.").

24 The Federalist Papers, ed. Clinton Rossiter (New York: New American Library, I96I), no. 84.

25 Howard, Road from Runnymede, 239-40.

26 Lutz, The Origins of American Constitutionalism, 62.

27 Helen E. Veit, ed., Creating the Bill of Rights: The Documentary Record from the First Federal Congress (Baltimore: Johns Hopkins University Press, I99I), 80.

28 Howard, Road from Runnymede, 230-36, 270-71; Neil H. Cogan, ed., The Complete Bill of Rights (New York: Oxford University Press, I997), 337-60; Little, "Differences over the Foundation of Law in Seventeenth- and Eighteenth-Century America," I36-54. 
legislative or judicial oversight. The second is more specific: the ability of churches to choose and control who serves as their ministers. ${ }^{29}$

\section{Historical Antecedents}

First, some background. As is known, the first chapter of Magna Carta concerns early church-state relations, by promising that the "English church shall be free." This clause, and its early appearance in the Carta, is likely due to the involvement of Archbishop Stephen Langton, among several other bishops, who was instrumental in its drafting. Langton included that clause to address the conflicts he and his predecessors had experienced with the crown. (Nine years earlier, King John had refused to acknowledge the pope's appointment of Langton as archbishop of Canterbury and primate of the church in England. Pope Innocent then excommunicated John which, along with a threatened invasion from France, led John to capitulate in $\mathrm{I} 2 \mathrm{I} 33^{3 \circ}$ ) Langton, no doubt, was also thinking of the "law investiture" controversy that had embroiled Pope Gregory VII and King Henry IV of Saxony, the Holy Roman Emperor, I 40 years earlier. Lay investiture was the prerogative of feudal lords to install their own candidates for high clerical office, rather than vesting that authority in the pope. The legend is that after Henry refused to surrender the right to appoint the next bishop of Milan, Gregory excommunicated him (a common medieval practice, no doubt), with the then remorseful Henry traveling to Gregory's alpine castle in Canossa in the middle of winter and kneeling barefoot in the snow for three days as a sign of contrition. Whether that episode is true or not, it came to stand for the independence of the church from the state, what Harold Berman touted as the "Papal Revolution," and a turning point in Western legal development. Berman overstated matters, for while Gregory won that battle, the wars over investiture continued across Europe for decades. Still the idea of "freedom of the church," building in part on Augustine's concept of two separate kingdoms, one temporal and the other spiritual, became embedded in the Western tradition. ${ }^{3}$

Of course, "freedom of the church" or "religious autonomy" has always been a rather protean concept, frequently representing an ideal rather than a reality. The struggle between the English

29 Two clauses of the Magna Carta apply:

(I) FIRST, THAT WE HAVE GRANTED TO GOD, and by this present charter have confirmed for us and our heirs in perpetuity, that the English Church shall be free, and shall have its rights undiminished, and its liberties unimpaired. That we wish this so to be observed, appears from the fact that of our own free will, before the outbreak of the present dispute between us and our barons, we granted and confirmed by charter the freedom of the Church's elections - a right reckoned to be of the greatest necessity and importance to itand caused this to be confirmed by Pope Innocent III. This freedom we shall observe ourselves, and desire to be observed in good faith by our heirs in perpetuity ....

(63) IT IS ACCORDINGLY OUR WISH AND COMMAND that the English Church shall be free, and that men in our kingdom shall have and keep all these liberties, rights, and concessions, well and peaceably in their fullness and entirety for them and their heirs, of us and our heirs, in all things and all places for ever.

Magna Carta (I 2 I 5), https://www.bl.uk/magna-carta/articles/magna-carta-english-translation.

30 J. C. Holt, Magna Carta, 2nd ed. (Cambridge: Cambridge University Press, I992), 216-18, 284-85; John W. Baldwin, "Due Process in Magna Carta: Its Sources in English Law, Canon Law and Stephen Langton," in Griffith-Jones and Hill, Magna Carta, Religion and the Rule of Law, 3I-52, at 47-48.

3 I Harold J. Berman, Law and Revolution: The Formation of the Western Legal Tradition (Cambridge, MA: Harvard University Press, 1983), 96-97; Frederick Mark Gedicks, “True Lies: Conossa as Myth,” Journal of Contemporary Legal Issues, no. 2I (2013): I33-44; Carl H. Esbeck, "Dissent and Disestablishment: The Church-State Settlement in the Early American Republic," BYU Law Review, no. 4 (2004): I385-I592, at I $407-8$. 
crown and the English church predated Magna Carta, as the tragic episode between Henry II and Thomas Becket demonstrated, and continued long after I 2 I 5. (Henry II had reputedly once sent a writ to the electors of the bishopric in Winchester stating: "I order you to hold a free election, but forbid you to elect anyone but my clerk Richard.") $3^{2}$ Even before Henry VIII's ascension as head of the Church of England, he and Cardinal Wolsey had already achieved effective control of the Catholic Church in England. The schism with Rome and resulting establishment of the (Protestant) Church of England only solidified that control. The Act of Supremacy of I 534 made the British monarch the supreme head of the church and the Act in Restraint of Annates, passed the same year, gave him authority to appoint the church's high officials. These were followed by several acts of uniformity with consolidation effectively completed with the Uniformity Act of I662 and Parliament's approval of the Book of Common Prayer the same year, the latter standardizing liturgical doctrine. As one scholar has noted, "[w]ith the Restoration, the Church began a period of a relatively settled and comfortable Erastianism," that is, a system where the state controls the church by determining doctrine and assigning offices. British governmental control over the Church of England would continue into the early twentieth century. ${ }^{33}$

As a result, the legacy that informed the American colonies and early states was not one of church autonomy pursuant to chapter I of Magna Carta but of submission and control of churches by temporal authorities. Leading up to the American Revolution, nine of thirteen colonies maintained some form of a religious establishment. A hallmark of the colonial establishments was the award of certain legal and property rights to officially approved churches. This occurred chiefly on a local level in New England with each town calling a pastor to be the "Settled Minister" of the Congregational Church and raising religious assessments to pay for a meeting house and for the minister's support. Authority to do so was delegated to towns by the Massachusetts General Court, and in 1636 the Court consolidated its control over individual churches by issuing an order prohibiting the formation of new churches without the permission of the local magistrate and a majority of elders. 34 The southern Anglican colonies replicated the Erastian situation in England, with the legislative assemblies exercising extensive authority over the operation of churches: dividing settlements into parishes; awarding land for church buildings, cemeteries, and glebe income; and assigning church vestries to manage the property holdings. In the absence of an American bishop-colonial priests were appointed by and answerable to the bishop of London-vestries made up of the political and economic elite (such as George Washington) effectively ran all local church affairs. ${ }^{35}$ Historian Thomas Curry has observed that because the Anglicanism of the colonies replicated the variety of religious perspectives found in Englandorthodox, latitudinarian, puritan-vestry leaders were able to adjust local worship according to their personal preferences. Also in the South, legislative assemblies ensured that established churches stayed true to official church doctrine, such as insisting on compliance with the Book of Common Prayer. In Virginia, in particular, the House of Burgess decided major issues concerning the operation and governance of the Anglican Church and resolved disputes involving

32 Quoted in Hosanna-Tabor Evangelical Lutheran Church and School v. Equal Employment Opportunity Commission, I30 S. Ct. 694, 702 (2013).

33 James W. Torke, “The English Religious Establishment," Journal of Law and Religion I2, no. 2 (I995-96): 399-445, at $406-8$.

34 Thomas J. Curry, The First Freedoms: Church and State in America to the Passage of the First Amendment (New York: Oxford University Press, I986), 6.

35 Edward L. Bond, Damned Souls in a Tobacco Colony: Religion in Seventeenth-Century Virginia (Macon: Mercer University Press, 2000), I77-222. 
individual parishes or the church in general. One could argue that the Erastian system was stronger in the southern colonies than it was in England, due in part to the lack of a church hierarchy. Thus, a leading indicia of the colonial religious establishments involved the political governance of the established churches, including government control of church property rights. ${ }^{36}$

Several factors provided the impetus for revolutionary disestablishment. Increasingly, people opposed the coercive nature of religious assessments that supported the established churches, even where the systems allowed people to assign their taxes to support their own churches (clearly, the Standing Order in New England believed that their system of multiple establishments resolved the coercion issue, but Baptists and other dissenters disagreed). Another factor supporting disestablishment was the concern over the preferential political treatment awarded to established churches and their members. Relatedly, colonists feared the civil authority exercised by official clergy and church bodies, which they saw as having a corrosive effect on republican government and individual rights. Many political leaders - James Madison, Thomas Jefferson, John Adams, among others - distinguished between rights of religious conscience, which they considered to be of highest importance, and institutional religion, which they viewed as susceptible of corruption (pursuant to their Whig leanings) and a frequent participant in political tyranny. Ecclesiastical power was something to be watched and controlled. Distrust of the power of clergy and church bodies was widespread, with Jefferson and Adams agreeing that both entities had corrupted the essence of Christianity. Writing in the early nineteenth century, Madison was still warning about "the danger of encroachment by Ecclesiastical Bodies." 37 Even revolutionary Protestant clergy agreed that "[p]ower, civil and ecclesiastical, ha[d] to be deflated, diffused, and properly related in order to keep it from becoming absolute, arbitrary, and abused.” For members of the founding generation, individual religious conscience was the superior value over the rights of institutional religion. ${ }^{38}$

Of lesser concern to the founders was the question of government control of churches, although that issue did occasionally arise. In his famous Memorial and Remonstrance, written in 1785 in opposition to Patrick Henry's proposed religious assessment bill in Virginia, James Madison insisted that religious matters were "not within the cognizance of civil government," and that Henry's bill "implie[d] either that the Civil Magistrate is a competent judge of religious truth, or that he may employ religion as an engine of civil policy." "If religion be exempt from the authority of the society at large," Madison argued, "still less can it be subject to that of the legislature." Madison's Memorial was supported by numerous petitions from dissenting churches, including the Hanover Presbytery, which in a rhetorical flourish declared that the principle of religious freedom affirmed in the Virginia Declaration of Rights, was the "Magna Carta of our Commonwealth." 39 Responding to these petitions, the Virginia Assembly rejected Henry's assessment bill, enacting in its stead Jefferson's Act for Establishing Religious Freedom which, among other matters, decried "the impious presumption of legislature and ruler ... who, themselves but

36 Thomas E. Buckley, Church and State in Revolutionary Virginia, I776-I787 (Charlottesville: University Press of Virginia, 1977), 5, 9-1 I; Curry, The First Freedoms, 30.

37 John Adams, "A Dissertation on Canon and Feudal Law" (I765), at http://teachingamericanhistory.org/library/ document/a-dissertation-on-the-canon-and-feudal-law/; James Madison, "Detached Memoranda" (I8I7), in The Sacred Rights of Conscience, ed. Daniel L. Dreisbach and Mark David Hall (Indianapolis: Liberty Fund, 2009), 589-93; Thomas Jefferson, Notes on Virginia (I78I), ibid., 484-86.

38 James H. Smylie, "Protestant Clergy, the First Amendment and the Beginnings of a Constitutional Debate, I78 I-9I," in The Religion of the Republic, ed. Elwyn A. Smith (Philadelphia: Fortress Press, I971), I I6-I 53, at I53.

39 "Memorial and Remonstrance" ( $\left.\mathrm{I}_{7} 85\right)$, in Church and State in American History: The Burden of Religious Pluralism, 2nd ed., ed. John F. Wilson and Donald L. Drakeman (Boston: Beacon Press, 1987), 69-70; Buckley, Church and State in Revolutionary Virginia, 26. 
fallible and uninspired men, have assumed domination over the faith of others." Later, as president, Jefferson would write in a letter that he interpreted the First Amendment of the Constitution as prohibiting "the government of the United States ... from intermeddling with religious institutions, their doctrines, discipline, or exercises." 40 Thus the theme of church autonomy from civil government, while not the leading factor behind disestablishment, was nonetheless viewed as an important principle in the new Republic. Still, for members of the founding generation, the rights of individual religious conscience were of primary concern. It is highly unlikely they would have supported the subordination of that right to the interests of institutional religion.

\section{Church Autonomy}

The issue of church autonomy from government interference arose most commonly with legal disputes over the control of church property. In the early nineteenth century, Protestant denominations distinguished themselves not only by their different religious doctrines but also by matters of church organization and polity. In the "spiritual hothouse" of the early republic, the democratizing impulses of the antebellum revivals, the competing and sometimes volatile faith claims, and the impending national conflict over slavery produced many church schisms, often resulting in disputes between factions over control of church property and assets. Most conflicts over property ownership involved churches with episcopate and presbyterian systems, where hierarchal officials and presbyteries held title to church buildings. (Schisms occurred within churches with congregational polities, as well, but with doctrinal and liturgical questions being decided by parishioners, not a higher body, a majority vote usually resolved ownership questions.) At times, disputes between warring factions ended up in civil courts, requiring judges to adjudicate competing claims involving matters of religious doctrine or polity. ${ }^{4}$

For the first half of the century, the prevailing rule in the United States was based on an I $8 \mathrm{I} 7$ English case, Attorney General v. Pearson, which had held that, in a dispute over church property, civil courts could determine which faction adhered closest to the traditional doctrines of the church, which in turn entitled it to ownership of the disputed property. Lord Eldon had written that it was the duty of a civil court "to inquire and decide for itself" not only the true authority of church adjudicatories, "but what [was] the true standard of faith in the church organization, and which of the contending parties ... holds to this standard." 42 The Pearson or "departure from doctrine" rule thus authorized civil courts to examine church doctrines and procedures and to determine which faction was correct and which was in error. The "departure from doctrine" rule was not limited to property disputes, however; once adopted, American courts applied it to settle other doctrinal claims, including the dismissal of clergy for theological reasons or whether a church's adoption of "new theological measures" contravened the testamentary intent of prior bequests. 43

State courts generally followed the Pearson rule throughout the antebellum era. In one case, the Pennsylvania Supreme Court in I 847 awarded the proceeds of a bequest to the faction of a

40 "Act for Establishing Religious Freedom" (I786), in Wilson and Drakeman, Church and State in American History, 73; Jefferson to Rev. Samuel Millar, Jan. 23, I808, in ibid, 79.

4I Jon Butler, Awash in a Sea of Faith: Christianizing the American People (Cambridge, MA: Harvard University Press, 1990), 225-56 (Butler coined the rich phrase "spiritual hothouse" to describe the expansive religious expression during the antebellum period.). This discussion is based on Steven K. Green, The Second Disestablishment: Church and State in Nineteenth-Century America (New York: Oxford University Press, 20IO), 22I-27.

42 Attorney General v. Pearson, 3 Merivale 353 (г8I7), quoted in Watson v. Jones, 80 U.S. 679, 724 (г87I).

43 Green, The Second Disestablishment, 22I-27. 
Lutheran congregation that had not ventured into "new measures, and new modes of worship." Civil judges had the duty, it wrote, "to decide in favour of those, whether a minority or a majority of the congregation, who are adhering to the doctrine professed by the congregation, and the form of worship ... with which it was connected at the time the trust was declared." 44 Antebellum judges applied the Pearson rule even though many recognized the tension in a civil court arrogating the authority to adjudicate matters of church governance and doctrine. The New Jersey Chancery Court wrote in I 832 that while it "utterly disclaim[ed] the idea that ... any court ... has a right to enforce a creed, or system of doctrine or belief," it "most unqualifiedly assert[ed] and maintain[ed] the power and right ... to ascertain, by competent evidence, what are the religious principles of any man." 45 American judges were apparently attempting to maintain the religious status quo in response to an increasingly divisive religious environment brought on by revivals and disputes over slavery. One court that applied the Pearson rule exclaimed that it was seeking to ameliorate the "discord," "division, heart-burning, and separation" that had been caused by a congregational schism following a revival.46

Over time, the tension that existed between the Pearson rule and notions of church-state separation began to weigh on judges. By midcentury courts began to impose limitations on the rule, stating that they would defer to the authority of religious tribunals on matters of doctrine except where the controversy involved civil or property rights in need of judicial protection. Other courts stated that their authority was limited to examining only a "substantial departure from the original faith" or "a radical change of faith or doctrine." 47 How those determinations were to be made, however, remained uncertain. In an I846 opinion, the Pennsylvania Supreme Court refused to follow the Pearson rule, writing that "decisions of ecclesiastical courts, like every other judicial tribunal, are final, as they are the best judges of what constitutes an offence against the word of God." Civil courts were "incompetent judges of matters of faith, discipline and doctrine." 48 Yet, the following year, the same court again relied on Pearson to determine which faction in a warring congregation adhered to the founding principles of the church and were entitled to control a sizable bequest. 49

Even though property and estate law were matters of state law, the US Supreme Court stepped forward to settle this legal uncertainty. At the close of the Civil War, a dispute arose in a Louisville, Kentucky, Presbyterian church over the issue of slavery. Having opposed slavery, the General Assembly of the (Northern) Presbyterian Church directed that ex-Confederate sympathizers could not become church members or be readmitted to membership until they repented for their sin of supporting slavery. This edict caused a schism within the Walnut Street Presbyterian Church with each faction claiming rightful ownership of the church building. The General Assembly sided with the antislavery faction while the proslavery faction claimed that the General Assembly had exceeded its authority under Presbyterian rules of governance. One side brought a diversity action in federal court, with the case eventually working its way to the Supreme Court. $5^{\circ}$

44 App. v. Lutheran Congregation, $6 \mathrm{~Pa}$. 201, 210 (I 847 ).

45 Hendrickson v. Shotwell, I N.J. Eq. 577, 633 (г832).

46 App. v. Lutheran Congregation, 6 Pa. at 210 ; Green, The Second Disestablishment, $22 \mathrm{I}-27$.

47 Mt. Zion Baptist Church v. Whitmore, 49 N.W. 8I, 86 (Iowa I89I); Philomath College v. Wyatt, 37 P. I022, I023 (Ore. I894).

48 German Reformed Church v. Commonwealth, 3 Pa. 282, 29I (I846).

49 App. v. Lutheran Church, 6 Pa. 201 (I 847); Green, The Second Disestablishment, 22 I-27.

50 Watson v. Jones, 80 U.S. 679 (I87I). 
In Watson $v$. Jones, the Court repudiated the Pearson rule, holding that civil courts could not generally adjudicate disputes between members of church congregations over the ownership and use of church property. Writing for the Court, Justice Joseph Miller held that this bar was particularly true where the dispute involved the interpretation of church doctrine or theology:

[T] he rule of action which should govern the civil courts, founded in a broad and sound view of the relations of church and state under our system of laws ... is, that, whenever the questions of discipline, or of faith, or ecclesiastical rule, custom, or law have been decided by the highest of these church judicatories to which the matter has been carried, the legal tribunals must accept such decisions as final, and as binding on them, in their application to the case before them. ${ }^{5}$

The ultimate decision in Watson was based on common-law principles of corporate and property law: "Religious organizations come before us in the same attitude as other voluntary associations for benevolent or charitable purposes and their right to property, or contract, are equally under the protection of the law," Miller wrote. ${ }^{52}$ But the justices also understood that there were First Amendment implications in applying the Pearson rule:

[I]n this country the full and free right to entertain any religious belief, to practice any religious principle and to teach any religious doctrine which does not violate the laws of morality and property, and which does not infringe personal rights, is conceded to all. The law knows no heresy, and is committed to the support of no dogma, the establishment of no sect. The right to organize voluntary religious associations to assist in the expression and dissemination of any religious doctrine, and to create tribunals for the decision of controverted questions of faith within the association, and for the ecclesiastical government of all the individual members, congregations, and officers within the general association, is unquestioned.53

Justice Miller's opinion implied that the Pearson rule was an anachronism based on authority that existed under the British religious establishment. In contrast, notions of free exercise and disestablishment prevented US courts from exercising similar authority over religious bodies when it came to matters of doctrine or organization. If civil courts were authorized "to inquire into all these matters, the whole subject of the doctrinal theology, the usages and customs ... and fundamental organization of every religious denomination" would be open for judicial consideration, Miller wrote. "This principle would deprive these bodies of the right of construing their own church laws, would open the way to all the evils which we have depicted as attendant upon the [departure from doctrine rule]." 54 With the decision, the Court established the autonomy of church doctrine and governance as a bedrock principle for American church-state relationships: "The structure of our government has, for the preservation of civil liberty, rescued the temporal institutions from religious interference," Miller wrote, and "it has secured religious liberty from the invasions of the civil authority." 55

Coming some seventy years before the incorporation of the religion clauses, the Watson holding was only advisory, not binding on state courts. The decision was nonetheless influential, as state courts gradually adopted its holding or increased limitations on the Pearson rule. Only three years following Watson, the New York Court of Appeals optimistically declared the new rule to

\footnotetext{
5 I Ibid., 727 .

52 Ibid., 7 I 4 .

53 Ibid., 728-29.

54 Ibid., 733-34.

55 Ibid., 730 .
} 
be "settled law," although it would take the remainder of the century for that to occur. ${ }^{6}$ Judges viewed the principle as benefitting both religious and civil institutions. "The structure of our government has, for the preservation of civil liberty, rescued the temporal institutions from religious interference," declared the South Carolina Court of Equity in mid-century. "On the other hand, it has secured religious liberty from the invasion of the civil authority." 57 The Nebraska Supreme Court concurred in I 895 , stating that churches "should be free from the interference of the courts where there is nothing drawn into question but the jurisdiction of the church over one of its members or ministers or officers." The court wrote that not only was this rule "thought to be the best policy, and consistent with good government," it was consistent with the principle that "the church and state [should] be completely severed, or as nearly so as may be and can be with due observance of all proper laws." ${ }^{8}$ By the early twentieth century, state courts had generally abandoned the Pearson rule while adopting rules similar to that in Watson. ${ }^{59}$

As noted, Watson involved a common law rule, not an interpretation of the First Amendment, but there was a clear constitutional ring to the decision. The Supreme Court finally addressed the issue of church autonomy from a constitutional standpoint in 1952, a decade after it had held that the First Amendment's religion clauses applied to actions of state and local governments, not solely the federal government. ${ }^{60}$ The case of Kedroff $v$. St. Nicholas Cathedral had an interesting Cold War backstory. In response to the Russian Revolution of I9I7, leaders of the Russian Orthodox Church in America had created a governing body in this country to oversee its American churches until the Russian government ceased persecuting the Orthodox Church. In the I930s, the now Communist controlled Moscow Patriarchate attempted to reassert its earlier authority over the American churches, particularly St. Nicholas Cathedral in New York City, the symbolic seat of the Russian Church. In response, the New York legislature passed a law in 1945 recognizing the authority of the Russian Orthodox Church in America to govern the domestic church and to possess and use St. Nicholas Cathedral. Relying on this New York law, a pro-American faction filed suit to wrest leadership of the church and possession of St. Nicholas Cathedral from a faction that recognized the authority of Moscow. ${ }^{61}$

Despite the Cold War overlay involving communist control over an American church, the Supreme Court held that the New York legislature had improperly intervened in this internal dispute about who was to govern the church and have control of St. Nicholas Cathedral. It reasserted the principle of Watson $v$. Jones, applying it now to legislative efforts at controlling internal church operations. That earlier decision, Justice Stanley Reed wrote, had established "a spirit of freedom for religious organizations, an independence from secular control or manipulation - in short, power to decide for themselves, free from state interference, matters of church government as well as those of faith and doctrine." This principle, Reed declared, "must now be said to have federal constitutional protection as a part of the free exercise of religion against state interference." ${ }^{62}$

In more recent cases the Court has qualified the breadth of the Watson rule by holding that civil courts may adjudicate internal church disputes where the controversy involves only applying "neutral principles of law developed for all property disputes" and does not call on civil courts to

56 Connitt v. Reformed Protestant Dutch Church, 9 Stickels 55 I, 562 (N.Y. I874).

57 Harmon v. Dreher, I Speers Eq. 87, I 20 (S.C. I 842).

58 Pounder v. Ash, 63 N.W. 48, 50 (Neb. I 895 ).

59 Green, The Second Disestablishment, $22 \mathrm{I}-27$.

60 Everson v. Board of Education, 330 U.S. I (I947).

6I Kedroff v. St. Nicholas Cathedral of Russian Orthodox Church in North America, 344 U.S. 94 (I952).

62 Ibid., I I6. 
adjudicate controversies over religious organization, doctrine, or practice. Still, the justices have reaffirmed the basic premise, arising in part from chapter I of Magna Carta, of the ability of churches to manage their own internal operations free from the control of the government, whether it be the legislature or the courts. The Constitution, the Court declared subsequently in I976, "permit[s] hierarchical religious organizations to establish their own rules and regulations for internal discipline and government, and to create tribunals for adjudicating disputes over these matters. When this choice is exercised and ecclesiastical tribunals are created to decide disputes over the government and direction of subordinate bodies, the Constitution requires that civil courts accept their decisions as binding upon them." ${ }^{6} 3$

Although this general principle of church autonomy can be traced to Magna Carta, in actuality, there is no direct evidence that the justices relied on chapter I of the Carta in making their pronouncements. A quick word search of the half-dozen religious autonomy cases turns up no mention of Magna Carta. That lack of direct evidence should not negate the possible "long shadow" of Magna Carta, embellished as it was by American colonialists, on American common law. As mentioned, the first church autonomy case, Watson, was decided on common law principles, from which one may see the general legacy of the Magna Carta. In this sense, there is a link between the American principle of church autonomy and Magna Carta. By the mid-nineteenth century, the idea of a "free church" was a well-established legal principle in the United States.

\section{Selection of Clergy}

One could argue that few issues concerning religious autonomy or "freedom of the church" are more significant than the ability of churches to select their own clergy. As noted, chapter I of the Carta was inspired in large part by the issue of lay investiture of clergy, and it confirmed "the freedom of the Church's elections." Despite that guarantee, lay or royal investitures of bishops and other high church officials continued, as did government control over the selection of ministers. The Uniformity Act of I662, for instance, limited service as a minister to those who formally assented to proscribed tenets and pledged to follow the mode of worship set forth in the Book of Common Prayer. Any minister who refused to make that pledge was "deprived of all his Spiritual Promotions." 64

Government control over the selection of ministers was followed in the American colonies. In Virginia and other Southern Anglican colonies, lay vestries exercised authority to hire and fire clergy and to determine their salary. According to Thomas Buckley, the vestry, acting under authority granted by the Assembly, "decided whether to induct a clergyman into the parish; that is to offer him tenure as rector. ... In short, the Virginia clergy were effectively controlled by lay administrators and deprived of religious leadership." ${ }_{55}$ This pattern was followed in other colonies. In New York, following the Glorious Revolution and the enactment of the Toleration Act of I689, the Assembly enacted the "Ministry Act" of $\mathrm{I} 693$ for the purpose of settling ministers in communities and providing maintenance for them. The Act provided for the election of ten vestrymen and two wardens in each parish to collect church taxes and call a minister based on an election by the majority of town freeholders. Anglican leaders argued that the Act established the Church of

63 Presbyterian Church v. Hull Memorial Presbyterian Church, 393 U.S. 440 (I969); Serbian Orthodox Diocese v. Milivojevich, 426 U.S. 696 (1976).

64 Act of Uniformity, I662, I4 Car. 2, ch. 4; Hosanna-Tabor Evangelical Lutheran Church and School v. Equal Employment Opportunity Commission, I30 S. Ct. 694, 703 (2013).

65 Buckley, Church and State in Revolutionary Virginia, Io. 
England in the colony, but the Assembly had cleverly required that ministers only be "good sufficient Protestants," which allowed communities with a majority of Presbyterians or Dutch Reformed to call ministers of their own faith and thus create their own mini-religious establishments. Despite this exercise in local democracy, ministers were still selected by a town majority acting under legislative authority, rather than by church members. ${ }^{66}$

A similar arrangement existed in the New England colonies and in those three statesMassachusetts, Connecticut, and New Hampshire-that maintained their religious establishments into the early nineteenth century. Under their congregational systems, town freeholders selected the settled ministers, not church leaders or members. This system raised little controversy until the rise of insurgent Unitarianism within the Congregational Church in the late I70os. Competing factions arose within settled churches, leading to schisms, with minority Unitarian factions often leaving and establishing their own churches. Then in 1820 , in the watershed case of Baker $v$. Fales, the Massachusetts Supreme Judicial Court reaffirmed that the majority of town freeholders, not church members, would elect the settled minister, even if they were non-Congregationalist or non-church-going. Thus Congregational churches and their members now had to suffer having a Unitarian or Universalist minister (and pay his salary as well!). The Baker holding, and its fallout, more than any other event, is responsible for the eventual disestablishment in Massachusetts in I $833 .{ }^{67}$

The idea of government control over a church's selection of its ministers now seems like a historic relic. The question was implicated in Kedroff, the Russian Orthodox Church case discussed earlier, as the challenged New York law had denied the authority of the Moscow Patriarch to appoint American bishops and clergy. Due to that factor, the Kedroff Court wrote that "Freedom to select the clergy, where no improper methods of choice are proven, we think, must be said to have federal constitutional protection as a part of the free exercise of religion against state interference." 68

Government interference in ministerial relationships has come in more subtle forms. Modern regulations of employment relationships, based in part on civil rights legislation, have arisen at a time that religious organizations have expanded their activities into areas shared by private and nonprofit businesses. Questions have arisen whether laws such as the National Labor Relations Act, guaranteeing collective bargaining of unions, the Fair Labor Standards Act, regulating maximum working hours and minimum wages, and the Equal Employment Opportunities Act, prohibiting employment discrimination based on race, gender, and religion, apply to religious organizations. In essence, can a federal or state law prohibiting employment discrimination based on gender force a church to hire a woman minister?69

The Supreme Court first considered these questions in a 1979 suit by the National Labor Relations Board against two Catholic high schools that objected to unionization by its lay teachers. The church leaders argued, in part, that lay teachers had to meet certain religious qualifications to teach and that some engaged in religious activities in the schools. The Court acknowledged the religious implications of allowing government jurisdiction over employment matters in religious schools, noting "the critical and unique role of the teacher in fulfilling the mission of a

66 John Webb Pratt, Religion, Politics and Diversity: The Church-State Theme in New York History (Ithaca: Cornell University Press, 1967), 37-46.

67 Baker v. Fales, I6 Mass. 488 (I 820 ); Green, The Second Disestablishment, I4 I-45.

68 Kedroff v. St. Nicholas Cathedral of Russian Orthodox Church in North America, 344 U.S. 94, I I6 (I952).

69 National Labor Relations Act, 29 U.S.C. $\$$ I 5 I, et seq. (I947); Fair Labor Standards Act, 29 U.S.C. $\$ 201$, et seq. (1938); Equal Employment Opportunity Act, 42 U.S.C. $\$ 2000$ (I964). 
church-operated school” particularly where "[r]eligious authority necessarily pervades the school system." Ultimately, however, the Court side-stepped the constitutional question, finding that Congress had not intended the Act to apply to religious schools. ${ }^{\circ}$

The more prominent source of government regulation of the employment decisions of religious entities has been the Equal Employment Opportunities Act, or EEOA, and more recently enacted employment nondiscrimination laws. As initially written in 1964, the EEOA ("Title VII") prohibited private employers with fifteen or more employees from discriminating on the basis of race, gender, and religion. Religious organizations were covered, but were exempted from the religious prohibition for those employees engaged in religious functions. Congress expanded that exemption in $\mathbf{9} 972$ to allow religious organizations to use religion as a qualification for all employees, regardless of whether they are engaged in carrying out the organization's religious mission. ${ }^{7 \mathrm{~T}}$ Thus a Methodist church could require that its minister be a Methodist in good standing, and its janitor as well. In 1987 the Supreme Court upheld this exemption, noting that a narrower rule would otherwise deny religious organizations the ability to decide for themselves who carries out their religious mission. Importantly, though, religious organizations-hospitals, schools, publishing houses-are still prevented from discriminating on nonreligious grounds, such as race, gender, or disability. $7^{2}$

The question quickly arose whether these remaining nondiscrimination requirements should apply to a church's selection of a minister. Title VII does not contain any special exemption for the hiring and firing of clergy, and several cases arose where ministerial candidates were allegedly denied positions based on racial, age, gender or disability discrimination. Noting that the ability of a church to select its clergy unimpeded represents the "life-blood" of the congregation or denomination, lower courts read an unlimited exemption into the law; in essence, to require a church to provide any explanation for refusing to hire a minister would place a significant burden on the independence of that church. Surprisingly, even though lower courts had recognized this "ministerial exception" as early as the I970s, the Supreme Court did not rule on the issue until 2013.73

Hosanna-Tabor Evangelical Lutheran School v. EEOC involved a teacher of secular subjects who claimed she was fired for a medical disability, in violation of the Americans with Disabilities Act, or ADA. The school responded that the teacher had accepted a "called" status, in that she satisfied certain religious requirements by her congregation to be called to her position as a teacher in a religious school. She also taught a class in religion and occasionally led prayer and devotional exercises. Thus the school claimed the teacher was a minister-of-sort, and that regardless it should be allowed to decide for itself who engages in ministerial functions. As a result, the school maintained it should be able to dismiss the teacher on any ground, religious or otherwise, without the fear of government oversight. 74

In a unanimous decision, the Supreme Court sided with the Lutheran school, finding that there was a constitutionally guaranteed "ministerial exception" to all employment nondiscrimination laws:

70 National Labor Relations Board v. Catholic Bishop of Chicago, 440 U.S. 490 (I979).

$7 \mathrm{I} 42$ U.S.C. $\$ 2000 \mathrm{e}-\mathrm{I}$ (1972). See generally, Steven K. Green, "Religious Discrimination, Public Funding, and Constitutional Values," Hastings Constitutional Law Quarterly 30, no. I (2002): I-55.

72 Corporation of the Presiding Bishop v. Amos, 483 U.S. 327 (1987).

73 See Leslie C. Griffin, “The Sins of Hosanna-Tabor," Indiana Law Journal 88, no. 3 (20I3): 98 I-IOI9, at I002-6.

74 Hosanna-Tabor Evangelical Lutheran Church and School v. Equal Employment Opportunity Commission, I30 S. Ct. 694, 702 (2013). 
The members of a religious group put their faith in the hands of their ministers. Requiring a church to accept or retain an unwanted minister, or punishing a church for failing to do so, intrudes upon more than a mere employment decision. Such action interferes with the internal governance of the church, depriving the church of control over the selection of those who will personify its beliefs. By imposing an unwanted minister, the state infringes the Free Exercise Clause, which protects a religious group's right to shape its own faith and mission through its appointments. According the state the power to determine which individuals will minister to the faithful also violates the Establishment Clause, which prohibits government involvement in such ecclesiastical decisions. 75

In reaching its decision, the Court traced the idea of church autonomy directly back to Magna Carta. It noted that the "freedom of elections," mentioned in the first chapter, was considered a right "thought to be of the greatest necessity and importance to the English church." Despite the intervening history in England and the British American colonies, this principle was implicitly included in the First Amendment's religion clauses, Chief Justice Roberts declared, a principle that was ultimately recognized in the Watson and Kedroff cases. "We cannot accept the remarkable view that the Religion Clauses have nothing to say about a religious organization's freedom to select its own ministers." Significantly, in contrast to the general church autonomy cases discussed earlier, the Hosanna-Tabor Court expressly identified the Magna Carta as establishing the underlying principle of a "free church."76

Apparently, no justices objected to the Court's reliance on Magna Carta for this principle. From where Chief Justice Roberts got the idea of relying on Magna Carta is uncertain. Two amicus briefs raised the legacy of chapter I for this principle, and the petitioner's merits brief implied as much. The matter was not briefed extensively, though possibly it should have been. With the assistance of Pope Innocent III, King John rescinded Magna Carta within ten weeks of its signing. John died conveniently of dysentery the following year. Moderate earls led by William Marshall, Earl of Pembroke, reissued the document in I2I 7 under the name of the ten-year old King Henry III. Henry formally issued the Magna Carta upon reaching majority in $\mathrm{I} 225$, but with several alterations. Important for our purposes was that the 1225 Carta, which became incorporated into British law in I297, omitted substantial parts of the first chapter of the I2I 5 version. Gone from chapter I for all future renditions was the clause relied on by Chief Justice Roberts: "that the liberty of elections which is deemed to be of the greatest importance and most necessary for the English church ... we granted and confirmed by our charter ... which we shall observe and wish to be observed by our heirs in perpetuity." 77 Apparently in thirteenth-century England, perpetuity had a ten-year shelf life. The point of this brief historical exegesis is that the principle of free election of clergy was not retained in the Magna Carta that became part of the British constitutional and common law system. Free election was not part of the heritage of Magna Carta or contained in the text that Coke and American colonialists came to venerate. And as discussed above, the free selection of clergy was not practiced in Great Britain or in colonial America for more than 500 years. Reliance on Magna Carta for this principle, or on subsequent practice in Britain and colonial America, is shaky at best. ${ }^{8}$

75 Ibid., 706

76 Ibid., 702, 706; Tore Lindholm, "Magna Carta and Religious Freedom," in Magraw, Martinez, and Brownell, Magna Carta and the Rule of Law, I93-226, at 220-23.

77 Magna Carta and the Rule of Law, XIII-XIv; Holt, Magna Carta, 378-405. My thanks to Professor Charles Donahue for bringing this point to my attention.

78 According to Holt, Coke never used the Charter of I 2 I 5 but based his commentaries on the I 225 reissue. Holt, Magna Carta, 20. 
The Hosanna-Tabor majority did not resolve one of the more troubling issues, of how much deference to afford a religious body in defining who is clergy or a minister. It was enough for the majority that the teacher had voluntarily sought the status as a "called teacher." Justice Thomas alone was willing to give churches a carte blanc to decide for themselves, while Justices Alito and Kagan, in concurrence, recommended a functional test. For lawyers who have been involved in such cases, this uncertainty is disconcerting, as church leaders have claimed the ministerial exception covers a host of positions, such as choir directors and organists. ${ }^{79}$ Still, the basic principle that churches shall be able to select their own clergy, free from government control and oversight, appears to be beyond challenge. It finds its legacy in the I2 I 5 Magna Carta, despite that clause's own tortured history.

A second troubling issue arises from the Hosanna-Tabor holding, based in part on its forced reliance on Magna Carta. The negotiation between King John and Archbishop Langton and the other bishops was over the freedom of the institutional church. It had nothing to do with broader principles of religious freedom. In essence, "granting freedom to the head of and to the organs of the one supremely dominant religion of England in the matter of selecting its officials and managing its own affairs [did] not institute, nor even anticipate, religious freedom in the realm." Once their "freedom" was secured, the leaders of the English Catholic Church were satisfied. Despite the Charter's legacy as a source of individual rights such as due process, it says nothing about individual religious freedom. According to one scholar,

included in the numerous freedoms granted by Magna Carta, there is no freedom for any of the king's subjects to modify their authorized religious belief, no freedom to revise their religious practices, [and] no freedom to alter their religious alliances. The Great Charter of Liberty assumes without argument that there is but one pertinent religion in the Angevin realm: the religion of the Roman Church....

In short: providing the Roman Church in Angevin England with a significant degree of autonomy is not providing for religious freedom in England, nor does it anticipate religious freedom in the future. ${ }^{80}$

In fact, by isolating "freedom of the church" as the only religious concern, and when that is juxtaposed against other provisions that $d o$ recognize other rights of individuals, one can surmise that the only form of religious freedom that Magna Carta supports is that of institutional church autonomy. ${ }^{81}$

Returning to Hosanna-Tabor, one issue the Court had to reconcile with its holding that there is a free exercise protected right of church autonomy was its 1990 decision of Employment Division $v$. Smith. In that earlier case, the Court repudiated almost three decades of First Amendment jurisprudence by holding that government imposed burdens on religious practice that occurred through neutral laws that were generally applicable to religion and non-religion alike would no longer receive constitutional scrutiny. ${ }^{82}$ Chief Justice Roberts acknowledged that the prohibition against retaliatory dismissal contained in the ADA - the basis of the teacher's legal claim - "is a valid and neutral law of general applicability," such that one would expect the religious school's defense to fail pursuant to the authority of Smith. Both the teacher and the EEOC pressed this argument. Roberts distinguished the situation of individual claimants from the interest at hand. "The present

79 Griffin, "The Sins of Hosanna-Tabor," I007.

8० Lindholm, "Magna Carta and Religious Freedom,” 201.

8I Ibid., I96 ("[I]t inescapably follows that Magna Carta did not provide for religious freedom. Nor was protection of religious freedom, conceived as shielding religious diversity and change, detectably anticipated by King John or by any coauthor of Magna Carta in I 2 I $5 . ")$.

82 Employment Division v. Smith, 494 U.S. 872 (I990). 
case ... concerns government interference with an internal church decision that affects the faith and mission of the church itself," Roberts wrote. In contrast, "Smith involved government regulation of only outward physical acts." Thus, the Smith-limitation on the free exercise clause does not apply to the ministerial exception, or apparently to church autonomy cases generally. ${ }^{83}$

While this limitation on Smith can be celebrated on one level, as numerous commentators have done, it has a troubling side. First, Roberts's distinction between internal decisions of a church affecting its "faith and mission" and "outward physical acts" deserving of less protection is artificial and collapses in reality. After all, the plaintiffs in Smith were penalized for engaging in an internal church sacrament comparable to the Christian Eucharist, one, however, that the government chose to regulate. More significant, Hosanna-Tabor effectively elevates the free exercise rights of churches and religious institutions over rights of individuals. Aside from the burden that an absolute ministerial exception places on employees and the incongruity it creates for enforcing otherwise salutary nondiscrimination laws-not insignificant issues ${ }^{84}$-the holding sets up a hierarchy of rights under free exercise: churches win against generally applicable laws, individuals lose. As discussed above, this turns on its head the likely priority the Founders assumed about which religious interests to be protected. As one scholar has argued, "such a top-down government differentiation of internal religious authority and significance is clearly at odds with a Madisonian taboo on governmental restrictions on conscience." ${ }_{5}$ In essence, "[i]nterpreting the Free Exercise Clause to protect religious institutions' rights against their members ignores the experience of the earliest Americans, who broke away from traditional religious organizations and pursued individual liberty." 86 This unfortunate reordering, however, is supported by the limitations contained in Magna Carta. The Court's decision to rely on the questionable authority of Magna Carta, while not preordaining the outcome, awarded the holding in Hosanna-Tabor with an undeserved aura of legitimacy.

\section{CONCLUSION}

Runnymede was a highly significant event in English constitutional history, and the document it produced has become a symbol of many important principles of law and individual rights. One principle that Magna Carta stood for was that "the church shall be free." Important as this idea was and is for notions of religious freedom, people should resist relying on Magna Carta for our modern understanding of this principle. As a foundation for religious freedom, the legacy of Magna Carta is mixed. Its idea of a church free from government control-an idea not original to the charter-was not followed in either Great Britain or colonial America. It should not be surprising, therefore, that when the Supreme Court came to establishing the principle of church autonomy, Magna Carta had little impact on that decision. As for the specific principle of free selection of clergy, Magna Carta's legacy is even more tenuous. And when it comes to the idea of religious

83 Hosanna-Tabor Evangelical Lutheran Church and School v. Equal Employment Opportunity Commission, I30 S. Ct. 694, 706-07 (2013).

84 Griffin, "The Sins of Hosanna-Tabor"; Caroline Marla Corbin, "The Irony of Hosanna-Tabor Evangelical Lutheran Church and School v. EEOC," Northwestern University Law Review I06, no. 2 (20I2) 95 I-7 I (originally published in Northwestern University Law Review Colloquy I06 (201 I): 96-I I0, http://scholarlycommons. law.northwestern.edu/cgi/viewcontent.cgi?article=1057\&context=nulr_online).

85 Lindholm, "Magna Carta and Religious Freedom,” 223.

86 Griffin, "The Sins of Hosanna-Tabor," 989. 
freedom writ large-particularly for the religious liberty interests of individuals-Magna Carta's legacy becomes troublesome. Aside from its historical error, the Hosanna-Tabor Court's reliance on Magna Carta for the principle of a constitutional "ministerial exception" is unfortunate as it sets up a hierarchy of interests. While that hierarchy of rights may be consistent with the 80o-year-old Magna Carta and it feudal authors, one can question its consistency with the priority of the Founders or its authenticity today. We can only conclude that even though Magna Carta's influence at the founding of American church-state constitutionalism was minimal, its mixed legacy has persisted.

\section{ACKNOWLEDGMENTS}

A version of this paper was presented at the conference "Magna Carta Today" at Dartmouth College, Hanover, New Hampshire, November 7, 2015. I appreciate the helpful comments of Charles Donahue, Ken Kersch, and Sono Bedi. 